\title{
SUNK COST ANALYSIS OF FREQUENCY SPECTRUM AUCTION PRICES IN INDONESIA USING DATA ENVELOPMENT ANALYSIS
}

\author{
Siti Kurnia Rahayu \\ Department of Accounting, Universitas Komputer Indonesia, Bandung, Indonesia \\ Aju Widya Sari \\ Directorate of Telecommunication of Kementerian Kominfo, Indonesia
}

\begin{abstract}
The purpose of this study is to investigate the sunk cost argument on the auction price of the frequency spectrum by measuring the efficiency of the frequency license fee paid by the auction winner. The efficiency method employs a nonparametric approach, namely Data Envelopment Analysis (DEA) with the Linear Programming method, with the hypothesis model tested using Path Analysis. The dataset under consideration was Indonesia's Big Three Service Providers (2015-2020). The results show that the spectrum auction price is efficient in its impact on service prices, revenues, and income taxes. The spectrum auction price has no effect, lending credence to the argument that the spectrum auction price is considered a sunk cost in the telecommunications industry. The research reason is that the higher the auction price, combined with the lower cost of service due to high competition, the harder it is for small businesses to win the auction. The winning bidder will remain under the control of the prominent organizers, so the government issues a merger policy for small businesses to compete in spectrum auction bids.
\end{abstract}

Keywords: Spectrum License Fee, Capital Expenditure, Service Pricing, Revenue, Income Tax

DOI: http://dx.doi.org/10.15549/jeecar.v9i1.879

\section{INTRODUCTION}

Since frequency spectrum is a natural resource with an economic potential that is inexhaustible, limited, non-renewable and ever-increasing demand, it is critical to use it efficiently and responsibly (ITU-R, 2018). Spectrum management by regulators must consider the impact of spectrum licensing fees on the telecommunications sector's viability. When combined with Income Taxes, Value Added Taxes, regulatory fees, and other fees; Exorbitant Spectrum Licensing Fees can harm growth opportunities and investment levels (ITU, 2016).
As a result, it is critical to consider this policy through planning that utilizes appropriate market-based methods following the goals of economic efficiency and adequate operational funding (ITU, 2016). Based on the experience of several countries, the auction method is the best frequency spectrum allocation method, where this method can determine the license winner who is considered able to use the spectrum effectively and efficiently to increase state revenues (ITU-R, 2018).

Governments frequently cite economists' views that payment for spectrum licenses is a 
Sunk Cost to justify auction success being measured by total revenue (GSMA, 2019). If licensees in the telecommunications industry determine consumer prices and make investment decisions based on the Spectrum License Fee, the company will not profit from the Spectrum License Fee (GSMA, 2019). The Spectrum License Fee argument is that the Sunk Cost is supported by research in 21 OECD countries that determine $3 \mathrm{G}$ spectrum through auctions and the Beauty Contest, which shows that the Spectrum License Fee does not affect the income of companies winning the auction (Park et al., 2010). This complies with Cambini and Garelli's (2017) findings, where consumer prices are high, the amount consumed, such as data or minutes, is low, and vice versa (Cambini and Garelli, 2017).

According to Kwerel (2000), fees paid for spectrum licenses in the auction are included in Sunk Cost. Therefore, Spectrum Auction Fees are considered irrelevant to price decisions regarding the company's output. According to Kwerel (2000), network operators view the spectrum license auction as a fee charged to customers in the consumer price component, which cannot be supported by empirical evidence in the United States. Furthermore, Morris (2005) and Bauer (2003) tested and found no evidence that license fees affect service prices, supporting the theory that auctioned license fees function similarly to rental taxes. Other studies have yielded conflicting results. Marsden (2017) explained that Sunk Cost is irrelevant to the company's investment decisions and the pricing of services. It is based on the economic theory that assumes that investment decisions cannot influence future choices and License Fees, as Sunk Costs do not account for the long-term dynamic effects of high-spectrum costs (Marsden et al., 2017).

According to Offerman and Potters (2006), the upfront cost of the Spectrum License Fee results in high short-term prices for consumers in markets with a small number of market participants, and the average price for consumers remains elevated long after the costs are incurred. According to Offerman and Potters (2006), the mechanism of allocating Fixed Costs or Auction Fees does not affect consumer price levels. Still, costs in markets with limited competition can raise consumer prices. According to Buchheit and Feltovich (2011), varying Sunk Costs can result in different consumer prices. Companies tend to choose high consumer price equilibrium with high Sunk Costs and medium to lower Sunk Costs. Companies tend to prefer low consumer price equilibrium. According to Janssen and Karamychev (2009), telecommunication companies that are not overly risky as auction bidders tend to win the auction and price their products higher afterward. According to Haan and Toolsema (2011), the level of debt influences post-auction consumer prices for the bidder who wins the auction with debt financing. Kuroda and Forero (2017) discovered a lower penetration rate in auction countries after studying 47 countries.

According to Matheson and Petit (2017), if the costs incurred to obtain spectrum licenses through auctions result in taxes on economic rents due to the limited supply of spectrum, it is still not permitted to stifle investment. Because the cost spectrum is input to investment decisions, the company provides a view of expected costs and revenues based on demand factors, input costs, regulations, policies, and competition, and then estimates the long-term profit or return on investment (CGMA, 2019). Licensing fees have no bearing on output prices (Matheson and Petit, 2017). Spectrum License Fees can raise a company's average cost and long-term impact on profitability. In the face of lower-than-expected revenue gains from frequency license ownership, the company is likely to increase consumer prices or reduce other investment plans. However, the cost of this spectrum may deter further investment and affect consumer-pricing strategies (CGMA, 2019). According to Hazlett, Munoz, and Avanzini (2011), the purpose of auctions should be to ensure that the most technically efficient providers receive licenses rather than to increase revenue. A mistaken emphasis on increasing revenue will limit the size and number of spectrum licenses because minimizing licensing costs results in less competition and higher service prices.

Taxes can be used to recover indirect costs associated with regulatory activities (such as spectrum licensing taxes) or to reflect the value of spectrum access. Indirect costs reflect the licensee's share of costs incurred for benefits not attributable to individual licensees and typically recover through taxes. Currently, indirect costs 
are recovered through spectrum licensing taxes and apparatus licensing taxes (DCA, 2017). The consensus on telecommunications taxation policies is that there are broader operational and economic benefits, as well as certain taxes and fees on communication consumption. Broader taxes based on consumption expenditures and income receipts are thought to have no negative impact on investment (GSMA, 2014).

In theory, limiting the supply of frequency spectrum as an input to the telecommunications industry following the Spectrum Auction Fee policy can impact the price of services to service users. The increase that occurs as a result of the auction policy determination impacts consumer prices, investment, and the taxes that the state will receive. As a result, it is expected that the spread of telecommunications services as one of the important engines of economic growth will be hampered because of the stipulation of the applicable frequency spectrum license fee regulations, which will affect investment and tax revenues.

Based on the explanation above, the purpose of this study is to assess the efficacy of frequency license fees obtained by telecommunications operators through auctions, as measured by the impact on service selling prices, revenue, and income tax. The novelty in this research is the efficiency measurement that examines the sunk cost argument at the auction price of the frequency spectrum.

\section{LITERATURE REVIEW}

Spectrum management encompasses activities such as spectrum use planning, spectrum allocation and licensing, coordination of shared spectrum use, synchronization of regional and global spectrum standards, and monitoring and control of actual usage (ITU-2016). The marketbased administration method is one method of price spectrum administration. Reserved Price $=$ Auction Base Price when using regulated incentive pricing (AIP), where the pricing by the regulator reflects the opportunity cost spectrum by including administrative incentive prices. Prices are set at levels that encourage efficient spectrum use while reflecting spectrum scarcity.

Economic principles that must be applied in the frequency spectrum management system (ITU-R SM.2012) include limited frequency spectrum resources, which necessitate optimal spectrum placement and effective frequency utilization. Spectrum costs are a source of State finance, which requires systematic determination and consideration of inflation; and the difference between spectrum fees and administration fees, where the administrative fees are used to pay for the services the authorities provide. Spectrum costing by regulators must meet certain criteria, such as meeting state budget goals, not refuting economic goals in national development and the development of new services, and providing all spectrum benefits. Meanwhile, the Reality Principles in determining spectrum costs by regulators include easy identification of frequency users. The choice of parameters for calculating basic spectrum costs must allow for value verification, the consensus of all participants in determining the cost system to produce a good collection rate (ITU-R SM. 2012).

Network operators and operators define network licenses as Spectrum License Fees that are included in Assets that are amortized annually. According to Matheson and Petit (2017), a spectrum license fee is a payment made by the operator in advance that is valid for the license term and can be recorded as a long-term investment (15 years). The license fee is calculated as part of the operator's or network operator's fixed cost structure (Fixed Cost), along with the investment and Overhead Cost.

According to Bauer (2003), competitive spectrum auctions have become a medium for allocating licenses for providers, which are typically private companies.

The spectrum license fee is a Sunk Cost that has no bearing on future investments (Marsden, 2017). According to Marsden (2017), Sunk Cost ignores the repetitive nature of auctions and investments in the telecommunications sector; when the spectrum is valued at more than market value, it can reduce its profits, which primarily become the return on investment. The spectrum license price has a unique structure. A large advance payment is typically financed internally by the company winning the tender, followed by an annual fee paid as a smaller rental fee (Marsden, 2017). This structure causes the licensee's funds to be diverted to more profitable investments, causing the company's investment management to allocate fewer funds for high spectrum costs (Marsden, 2017).

Taxes and Fees on Communications Services vary greatly depending on the technology 
exercised; the Sales Tax and Fees on Communications Services apply, and the Corporate Income Tax of Communications Services is taken into account. The Spectrum License Fee paid by the communication service provider company is an exception (Tuerck et al., 2007). When the Spectrum Licensing Fee and Operator Tax raise the price of a communications service, the value spent by consumers is reduced by the price to be paid, resulting in lost consumer surplus. Whereas producers selling fewer units results in a loss of producer surplus. This total lost surplus is referred to as deadweight loss (Ellig and Taylor, 2007). In terms of revenue, communications service taxes and fees are regressive. High communications taxes and fees result in low purchasing power for communications services, potentially resulting in a digital gap. The low cost of communication services without reducing state revenues from the tax sector has become a government concern and strategy (Campbell R.M, 1984). When communication services are made more affordable by lowering costs and tax burdens, the impact on tax revenues from the provider's income sector is reduced (GSMA, 2007).

Taxes and Fees related to the provision of Telecommunication Services can influence the decisions of Service Providers, where higher expenses can lead to higher operating costs and reduce returns on capital expended and investment (McKenzie \& Mintz, 1992). The impact of less effective taxation is likely to limit the development of telecommunications infrastructure for economic development. The tax burden and fees charged on service providers can reduce investment capacity in the development of telecommunications infrastructure, thereby reducing growth and productivity (GSMA, 2013). Tax and fee regulations are important requirements in developing telecommunications infrastructure (World Bank, 2009). The effects of network

$$
\underset{\operatorname{Max}_{j} v_{j}}{E_{k}=\frac{\sum_{j=1}^{q} u Y_{k j}-u_{0}}{\sum_{i=1}^{p} v X_{k i}}} \quad \text { Subject to, } \frac{\sum_{j=1}^{q} u_{j} Y_{k j}-u_{0}}{\sum_{i=1}^{p} v X_{k i}}
$$

externalities arising from the telecommunications service sector must also be considered when assessing the impact of Taxes and Fees charged on the Operator (GSMA, 2014).

The tax system's complexity and transparency have been identified as a source of uncertainty for domestic and international investors in the telecommunications sector (Euronews, 2013). Tax uncertainty may result in lower levels of investment, so taxes are regarded as a significant barrier to investment. It is associated with tax instruments and the implementation of the Taxation Law and taxpayer limitations, which can stymie investment (IFG, 2009).

\section{METHOD}

This study aims to collect all data on Spectrum License Fees charged by Service Providers, Service Prices (Tariffs) charged to service consumers, and Taxes paid by Service Providers in Indonesia. The analyzed dataset is based on the Financial Statements of Indonesia's Big Three Service Providers (2015 - 2020).

The data analysis method employs quantitative methods to obtain quantitative data analysis results to respond to the sunk cost argument for spectrum license fees in terms of service tariffs and corporate income tax. The process for measuring efficiency employs a nonparametric approach, namely Data Envelopment Analysis (DEA), in conjunction with a linear programming method. The efficiency with DEA is technical, and it can be achieved with input variables, mediating variables, output variables, and technical cost measurement. The Banker, Charnes, and Chopper (BCC) model is used in the DEA method, and each input does not necessarily produce an output in the same proportion. Convexity conditions with non-negative element constraints are included in the BCC model. Model 4 of the DEA BCC model (Cooper et al., 2006; Chen et al., 2008) equation:

Where:

$\mathrm{E}_{\mathrm{k}}$ : Efficiency of ${ }_{\mathrm{k}}^{\text {th }} \mathrm{DMU}$

Q: Output

P: Input

$\mathrm{u}_{\mathrm{j}}$ : weight of output

$\mathrm{V}$ : weight of input

$\mathrm{U}_{\mathrm{o}}$ : scalar free in sign 
The formula in the BCC model calculates the efficiency of the most efficient DMU and DMU located on a convex line that creates an efficient limit after passing through the DMU area. Figure 1 depicts the BCC model's production limits graphically.

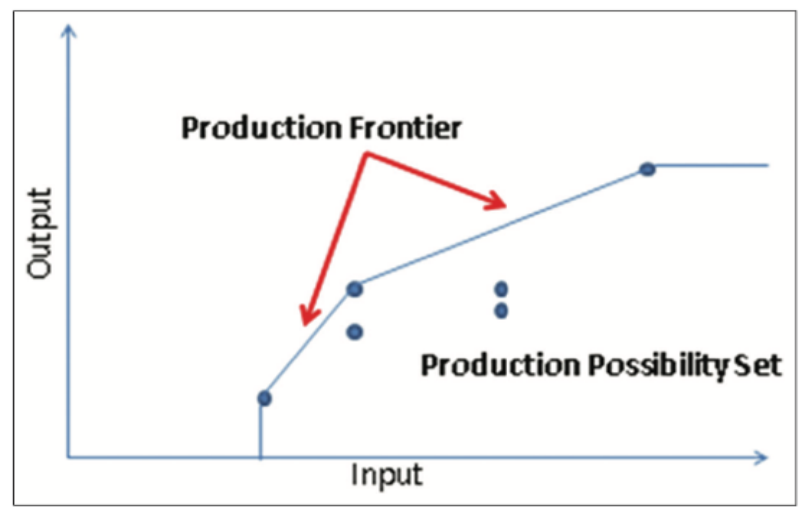

Figure1: Production frontier of the BBC model (adopted from Cooper et al., 2006)

Cost technical efficiency is measured using input variables such as Spectrum License Fees. Intermediate output variables are Capex and service prices. Income and Income Tax paid by the operator are the output variables. The relative efficiency of Economic Decision Units (UKE) is measured with multiple inputs and outputs. UKE's relative efficiency is defined as a Total Weighted Output/Total Weighted Input ratio $>1$. The Economic Decision Units (UKE) studied were Indonesia's Big Three Telecommunication Service Providers.

The application program used is DEAP Software Version 2.1, which generates a relative technical efficiency value between the UKEs being compared. It is used as a reference for other UKEs to improve their efficiency level if it generates a score of 1 . Those who obtain a score of $<1$ are considered inefficient.

The relationship of each variable studied was extended to collect data and test the hypothesis. This study's hypotheses are:

- BHP Frequency Affects Capex (H1);

- BHP Frequency Affects Service Tariffs (H2);

- Capex affects Income (H3),

- Capex affects Income Tax (H4),

- Service Tariffs affect Income (H5),

- Service Tariffs affect Income Tax (H6).

Path Analysis was used to analyze the data, which was done with the SPSS Version 20.0 software application. The REM (Random Effect Model) approach is used in the panel regression with Path Analysis because the test criteria reject $\mathrm{HO}$ if X2count > X2table and p-value are significant. Hypothesis testing is used to determine the effect of the independent variable on the dependent variable, and it includes the Partial Test (t-test) and Simultaneous Test (F test). When using significance level $\langle=0,05$, the hypothesis formulation states that $\mathrm{Hi} ; \AA 1=\AA 2=$ ®3 0 (no significant effect of the independent variable on the dependent variable). If $t_{\text {count }}>t_{\text {table, }}$, the independent variable has no significant effect on the dependent variable. If $t_{\text {count }}>t_{\text {table }}$, then the independent variable influences the dependent variable only partially. If $\mathrm{F}_{\text {count }}<\mathrm{F}_{\text {table }}$, then all independent variables affect the dependent variable simultaneously.

The Coefficient of Determination (R2) is used to calculate the significant effect of each variable, both partially and simultaneously. The coefficient value ranges from 0 to 1 , with a value close to 1 indicating that the independent variables provide nearly all of the information required to predict the variation of the dependent variable.

\section{RESULTS AND DISCUSSION}

This study's findings are based on the DEA design, employing one input variable, two mediating input variables, and two output variables. The model is calculated using the constant returns to scale (CRS) and variable returns to scale (VRS) assumptions (VRS). The three major network operators have varying efficiency levels based on the Efficiency test results (shown in Table 1). Telkomsel's average technical efficiency (vrste) is 94.3 percent, XL Axiata's is 99.54 percent, and Indosat's is 91.4 percent. These findings indicate that the operator's frequency license fees did not provide financial, operational efficiency during the study period. Telkomsel and Indosat achieved efficiency = 1 (constant return scale) in 2017 and 2019, while XL Axiata achieved it in 2015 and 2019. Indosat was the operator experiencing declining returns to scale (drs) in 2020.

Between 2017 and 2019, Telkomsel's management was the most effective in evaluating efficiency concerning this research model. The efficiency in 2015 was lower than it had been in both years. Although Telkomsel's revenue increased compared to previous years, 
2020 did not demonstrate an efficient value. The increase in income is due to extremely high service needs early this year due to the government's Work From Home policy as a result of Covid-19. In contrast to Telkomsel, for Indosat, 2020 is a year of increasing revenue accompanied by efficiency values indicating declining returns to scale (drs). According to this research model, Indosat has an effective efficiency value in 2017 and 2019. Similarly, even as revenue grew in 2020, XL Axiata's efficiency shows decreasing returns to scale (drs). XL Axiata demonstrates efficiency in 2015 and 2019 under optimal conditions

Table 1: DEA Efficiency Value

\begin{tabular}{|l|c|c|c|c|c|}
\hline \multicolumn{7}{|c|}{ Descriptive Statistics - Telkomsel } \\
\hline & $\mathrm{N}$ & Minimum & Maximum & Mean & Std. Deviation \\
\hline crste & 6 &, 131 & 1,000 &, 59650 &, 379072 \\
\hline vrste & 6 &, 810 & 1,000 &, 94317 &, 079665 \\
\hline se & 6 &, 131 & 1,000 &, 62683 &, 376815 \\
\hline Valid N (listwise) & 6 & & & & \\
\hline
\end{tabular}

\begin{tabular}{|l|c|c|c|c|c|}
\hline \multicolumn{7}{|c|}{ Descriptive Statistics - Indosat } \\
\hline & $\mathrm{N}$ & Minimum & Maximum & Mean & Std. Deviation \\
\hline crste & 6 &, 108 & 1,000 &, 64750 &, 408437 \\
\hline vrste & 6 &, 706 & 1,000 &, 91450 &, 134563 \\
\hline se & 6 &, 139 & 1,000 &, 66433 &, 384106 \\
\hline Valid N (listwise) & 6 & & & & \\
\hline
\end{tabular}

\begin{tabular}{|l|c|c|c|c|c|}
\hline \multicolumn{7}{|c|}{ Descriptive Statistics - XL Axiata } \\
\hline & $\mathrm{N}$ & Minimum & Maximum & Mean & Std. Deviation \\
\hline crste & 6 &, 814 & 1,000 &, 90250 &, 081294 \\
\hline vrste & 6 &, 972 & 1,000 &, 99533 &, 011431 \\
\hline se & 6 &, 830 & 1,000 &, 90650 &, 076519 \\
\hline Valid N (listwise) & 6 & & & & \\
\hline
\end{tabular}

Source: DEAP processing Version 2.1

According to the DEA efficiency scale shown in Table 2, the efficiency of BHP frequencies was not demonstrated by the value of Capex, service tariffs, revenues, and taxes for Telkomsel in 2015, 2016, 2018, and 2020. As for Indosat, it was not demonstrated in 2015, 2016, 2018, and 2020. For XL Axiata, this case occurred in 2016, 2017, 2018, and 2020. When the company issued an allocation fee for the frequency auction BHP as a cost in its operations, it did not provide a highefficiency value, maximum annual on Capex, pricing of services and revenues, and tax contributions to the government. The financial performance of the organizers, in general, was unaffected, mainly when their performance improved in the 2020 period. Telkomsel, Indosat, and XL Axiata were all at least twice in the frontier (crs).

Winners of spectrum licenses are considered efficient because they can pay higher-value license fees, increasing their income. According to DEA testing, spectrum license holders designated as efficient providers cannot fully support their increasing income.

The Spectrum License Fee is a long-term investment that is determined as part of the network operator's Fixed Cost structure, in addition to the Overhead Cost. Based on this assumption, BHP Frequency as a fixed cost and overhead cost, in general, does not provide an efficient value to Capex, and service rates indicate that BHP Frequency is a sunk cost. The spectrum license fee is a Sunk Cost that has no bearing on future investments. According to Bauer (2003), competitive spectrum auctions have become a medium for allocating licenses for providers, which are typically private companies. The government holds auctions to ensure that spectrum licenses are allocated to the most efficient telecommunications operators capable of generating State Revenue. The government's spectrum license bidder is considered efficient 
because they are also able to pay several license fees that are generally greater in value than the cost to exploit the network. For this reason, the bidder will have the highest rating and can win the bid because they have the greatest ability to increase its revenue (Cramton, 2002).

Table 2: Frontier Composition

\begin{tabular}{|c|c|c|c|c|c|c|}
\hline Providers & Year & crste & vrste & scale & crs/drs/irs & $\mathrm{E} / \mathrm{TE}$ \\
\hline \multirow{8}{*}{ Telkomsel } & 2015 & 0.131 & 1.000 & 0.131 & irs & TE \\
\hline & 2016 & 0.187 & 0.882 & 0.212 & irs & TE \\
\hline & 2017 & 1.000 & 1.000 & 1.000 & crs & $E$ \\
\hline & 2018 & 0.686 & 0.967 & 0.709 & irs & TE \\
\hline & 2019 & 1.000 & 1.000 & 1.000 & crs & $\mathrm{E}$ \\
\hline & 2020 & 0.575 & 0.810 & 0.709 & irs & TE \\
\hline & Mean & 0.596 & 0.943 & 0.627 & & \\
\hline & \multicolumn{4}{|c|}{ Number of crs } & 2 & \\
\hline \multirow{8}{*}{ Indosat } & 2015 & 0,108 & 0,781 & 0,139 & irs & TE \\
\hline & 2016 & 0,168 & 0,706 & 0,238 & irs & $\mathrm{TE}$ \\
\hline & 2017 & 1,000 & 1,000 & 1,000 & crs & $E$ \\
\hline & 2018 & 0,717 & 1,000 & 0,717 & irs & TE \\
\hline & 2019 & 1,000 & 1,000 & 1,000 & crs & $E$ \\
\hline & 2020 & 0,892 & 1,000 & 0,892 & drs & TE \\
\hline & Mean & 0,648 & 0,914 & 0,664 & & \\
\hline & \multicolumn{4}{|c|}{ Number of crs } & 2 & \\
\hline \multirow{8}{*}{ XL Axiata } & 2015 & 1,000 & 1,000 & 1,000 & crs & $E$ \\
\hline & 2016 & 0,830 & 1,000 & 0,830 & irs & TE \\
\hline & 2017 & 0,814 & 0,972 & 0,838 & irs & $\mathrm{TE}$ \\
\hline & 2018 & 0,899 & 1,000 & 0,899 & irs & TE \\
\hline & 2019 & 1,000 & 1,000 & 1,000 & crs & $\mathrm{E}$ \\
\hline & 2020 & 0,872 & 1,000 & 0,872 & drs & TE \\
\hline & Mean & 0,902 & 0,995 & 0,906 & & \\
\hline & \multicolumn{4}{|c|}{ Number of crs } & 2 & \\
\hline
\end{tabular}

Results from DEAP Version 2.1

Note: crste $=$ technical efficiency from CRS DEA vrste $=$ technical efficiency from VRS DEA

Scale $=$ scale efficiency $=$ crste $/$ vrste

$\mathrm{E}=$ Efficient, $\mathrm{TE}=$ Not Efficient

Communication Service Taxes are subject to Value Added Tax and include Corporate Income Tax. The Spectrum License Fee is not subject to taxation. When the Spectrum License Fee and Operator Tax raise the price of communication services, the overall efficient value for the three providers is lost. The value of consumer surplus from sales demonstrates the relationship between the service tariff model and income and impacts tax paid. The tax is graduated based on the organizer's income. The relationship between the frequency fees paid does not provide an efficient value on taxation. The cost of communication services continues to rise to the state revenues from the tax sector.

Based on the model selection test in panel data regression, the best model was a random effect model, with the results shown in the tables below.

\section{Effect of Frequency Fees on Capital Expenditure}

The statistical t-test is used to conduct the test. The test results show in Table 3 that the $t_{\text {count }}$ value of the Frequency Cost variable $(1.251)<$ is $t_{\text {critical }}(1.96)$ at the 5\% error level to accept Ho on 
H1. If the p-value for the Frequency Cost variable (X1) is $0,085>0.05$, then $\mathrm{HO}$ is accepted, implying that Hypothesis 1 is rejected, namely that the Frequency Cost has no significant effect on Capital Expenditure (Capex).

Table 3: Coefficients

\begin{tabular}{|c|c|c|c|c|c|}
\hline \multirow[t]{2}{*}{ Model } & \multicolumn{2}{|c|}{ Unstandardized Coefficients } & \multirow{2}{*}{$\begin{array}{c}\begin{array}{c}\text { Standardized } \\
\text { Coefficients }\end{array} \\
\text { Beta }\end{array}$} & \multirow[t]{2}{*}{$\mathrm{t}$} & \multirow[t]{2}{*}{ Sig. } \\
\hline & B & Std. Error & & & \\
\hline $\begin{array}{ll}1 & \text { (Constant) } \\
\mathrm{X}\end{array}$ & $\begin{array}{r}8998,495 \\
-, 001\end{array}$ & $\begin{array}{r}9170,522 \\
, 023\end{array}$ &,- 063 & $\begin{array}{r}981 \\
1,251\end{array}$ & $\begin{array}{l}341 \\
, 805\end{array}$ \\
\hline
\end{tabular}

a. Dependent Variable: Y1- Capex

Frequency Fees have a 0.4 (zero point four) percent impact on Capital Expenditure (Table 4). It means that the operator's investment value in running its operations only contributes to a 0.4 percent increase in frequency costs.

Table 4: Model Summary

\begin{tabular}{|l|r|l|l|l|}
\hline Model & \multicolumn{1}{|c|}{$\mathbf{R}$} & \multicolumn{1}{|c|}{ R Square } & Adjusted R Square & Std. Error of the Estimate \\
\hline 1 &, $063^{\mathrm{a}}$ &, 004 &,- 058 & 23348,084 \\
\hline
\end{tabular}

a. Predictors: (Constant), X-BHP Frequency

b. Dependent Variable: Y1- Capex

\section{Effect of Frequency Fees on Service Tariffs}

The test results show in Table 5 that the $t_{\text {count }}$ value of the Frequency Cost variable $(1.945)<$ is critical (1.96), so it was decided to accept Ho in $\mathrm{H} 2$ with a $5 \%$ error rate. If the p-value for the
Frequency Cost $(\mathrm{X} 1)$ variable is $0,068>0.05$, then $\mathrm{HO}$ is accepted for Hypothesis 2, implying that the Frequency Fee has no significant effect on service tariffs.

Table 5: Coefficients

\begin{tabular}{|ll|c|c|c|c|c|}
\hline \multirow{2}{*}{ Model } & \multicolumn{2}{|c|}{ Unstandardized Coefficients } & Standardized Coefficients & \multirow{2}{*}{ t } & \multirow{2}{*}{ Sig. } \\
\cline { 2 - 7 } & B & Std. Error & Beta & & \\
\hline \multirow{2}{*}{1} & (Constant) & 43889,637 & 18402,121 & &, 385 &, 030 \\
$\mathrm{X}$ &, 011 &, 006 &, 439 & 1,945 &, 068 \\
\hline
\end{tabular}

a. Dependent Variable: Y2-Service Tariffs

Frequency Fee has a 19.3 (Nineteen points three) percent impact on Service Tariff (Table 6). It means that the Service Tariff in the ARPU offered by the provider when selling the company's service products contributes only a 19.3 (nineteen points three) percent increase from the frequency fee.

Table 6. Model Summary

\begin{tabular}{|l|c|c|c|c|}
\hline Model & $\mathbf{R}$ & R Square & Adjusted R Square & Std. Error of the Estimate \\
\hline 1 &, $439^{\mathrm{a}}$ &, 193 &, 142 & 46851,669 \\
\hline
\end{tabular}

a. Predictors: (Constant), $\mathrm{X}$ 
Effect of Capital Expenditure and Service Rates on Revenue

The test results show in Table 7 that the $t_{\text {count }}$ value of Capital Expenditure variable $(1,694)<$ is critical (1.96), and with a $5 \%$ error rate, it was decided to accept Ho as the answer for H3. If the p-value for the Capital Expenditure (Y1) variable is $0,110>0.05, \mathrm{HO}$ is accepted for Hypothesis 3, indicating that Capital Expenditure has no effect on income.

The t-count value of the Service Tariff variable (4.914) $>$ is $t_{\text {critical }}$ (1.96). Therefore, H0 was rejected on $\mathrm{H} 4$ with a $5 \%$ error rate if the $\mathrm{p}$-value for the Service Tariff variable (Y2) is $0.000<0.05$, $\mathrm{HO}$ is rejected, and Ha is accepted for Hypothesis 4 , indicating that service rates influence revenue.

Table 7: Coefficients

\begin{tabular}{|c|c|c|c|c|c|}
\hline \multirow[t]{2}{*}{ Model } & \multicolumn{2}{|c|}{$\begin{array}{l}\text { Unstandardized } \\
\text { Coefficients }\end{array}$} & Standardized Coefficients & \multirow[t]{2}{*}{$\mathrm{t}$} & \multirow[t]{2}{*}{ Sig. } \\
\hline & B & Std. Error & Beta & & \\
\hline (Constant) & 2046,165 & 950,733 & & 2,152 & ,047 \\
\hline Y1 & ,069 & 041 & 390 & 1,694 & 110 \\
\hline Y2 & ,017 & ,004 &, 776 & 4,914 & ,000 \\
\hline
\end{tabular}

a. Dependent Variable: Z1- Revenue

According to the test results (Table 8), the $\mathrm{F}_{\text {count }}$ value is 2.869, with a p-value (sig) of 0.110 . Because the p-value $>\alpha(0.110>0.05), \mathrm{HO}$ is accepted, indicating that both Capex and service rates do not affect revenue.

Table 8: ANOVA $^{\mathrm{a}}$

\begin{tabular}{|c|c|c|c|c|c|c|}
\hline & Model & Sum of Squares & df & Mean Square & $\mathrm{F}$ & Sig. \\
\hline \multirow{3}{*}{1} & Regression & 42226536,367 & 1 & \multirow{3}{*}{$\begin{array}{l}42226536,367 \\
14719503,203\end{array}$} & \multirow[t]{3}{*}{2,869} & \multirow[t]{3}{*}{, $110^{b}$} \\
\hline & Residual & 235512051,244 & 16 & & & \\
\hline & Total & 277738587,611 & 17 & & & \\
\hline
\end{tabular}

a. Dependent Variable: Z1 - Revenue

b. Predictors: (Constant), Y1- Capex, Y2-Service Tariffs

The combined effect of Capital Expenditure and Service Tariff on Revenue is 15.2 (fifteen points two) percent (Table 9). This means that Capex and Service Tariffs both contribute to an increase in revenue of 15.2 percent, with the remainder influenced by other factors not examined in this study (84.8 percent).

Table 9. Model Summary

\begin{tabular}{|l|c|c|c|c|}
\hline Model & $\mathbf{R}$ & R Square & Adjusted R Square & Std. Error of the Estimate \\
\hline 1 &, $390^{\mathrm{a}}$ &, 152 &, 577 & 740,798 \\
\hline
\end{tabular}

a. Predictors: (Constant), Y1 Capex, Y2 Service Tariffs

b. Dependent Variable: Revenue

Partially, the effect of Capex on income shown in Table 10 is 3.3 percent $(0.119 x 0.277)$. At the same time, the effect of service tariffs on revenue is only 11.9 percent $(0.231 \times 0.515)$.

Table 10: Coefficients

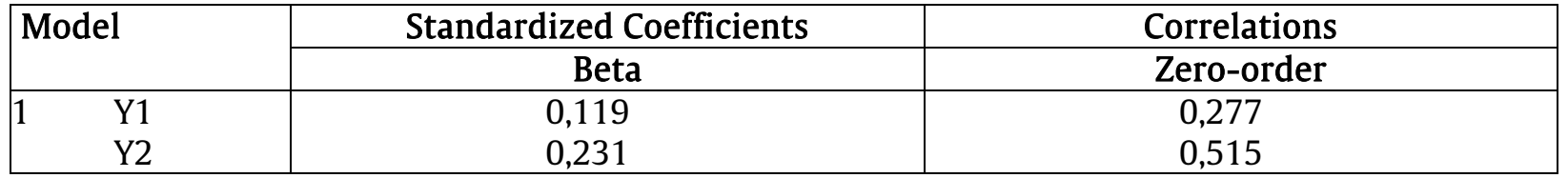

a. Dependent Variable: Z1 - Revenue 


\section{Effect of Capital Expenditure and Service Rates on Tax}

The test results show in Table 11 that the $t_{\text {coun }} t$ value of the Capital Expenditure variable (7.513) is $>t_{\text {critical }}$ (1.96), so it was decided to reject $\mathrm{HO}$ on $\mathrm{H} 5$ with a $5 \%$ error rate. If the p-value for the Capital Expenditure variable (Y1) is $0.000<0.05$, then $\mathrm{Ha}$ is accepted for Hypothesis 5, indicating that Capital Expenditure has an effect on Income Tax.

The t-count value of the Service Tariff variable (4.914) is $>t_{\text {critical }}(1.96)$, and at a $5 \%$ error rate, it was decided to reject Ho in Hypothesis 6. The pvalue for the Service Tariff variable (Y2) was $0.000<0.05$, then $\mathrm{HO}$ was rejected, and Hypothesis 6 was accepted. This implies that service Rates Influence Income Tax.

Table 11: Coefficients ${ }^{\mathrm{a}}$

\begin{tabular}{|c|c|c|c|c|c|}
\hline \multirow[t]{2}{*}{ Model } & \multicolumn{2}{|c|}{ Unstandardized Coefficients } & \multirow{2}{*}{$\begin{array}{c}\begin{array}{c}\text { Standardized } \\
\text { Coefficients }\end{array} \\
\text { Beta }\end{array}$} & \multirow[t]{2}{*}{$\mathrm{t}$} & \multirow[t]{2}{*}{ Sig. } \\
\hline & B & Std. Error & & & \\
\hline (Constant) & 2046,165 & 950,733 & & 2,651 & ,000 \\
\hline Y1 & ,069 & ,041 & ,390 & 7,513 & ,000 \\
\hline Y2 & ,017 & ,004 & ,776 & 4,914 &, 000 \\
\hline
\end{tabular}

a. Dependent Variable: Z2- Tax

The $\mathrm{F}_{\text {count }}$ value is 33,811 with a p-value (sig) of 0.000 based on the test results (Table 12), because of the p-value $<\alpha(0.028<0.05), \mathrm{HO}$ is rejected, indicating that capex and service rates significantly affect income tax.

Table 12: ANOVA $^{\mathrm{a}}$

\begin{tabular}{|ll|l|c|c|c|c|}
\hline & Model & Sum of Squares & df & Mean Square & F & Sig. \\
\hline \multirow{4}{*}{1} & Regression & 414268736,167 & 2 & 42226536,367 & 33,811 &, $028^{\mathrm{a}}$ \\
& Residual & 277712051,244 & 11 & 14719503,203 & & \\
\cline { 2 - 5 } & Total & 212338587,611 & 18 & & & \\
\hline
\end{tabular}

a. Dependent Variable: Z1- Revenue

b. Predictors: (Constant), Y1- Capex, Y2-Service Tariffs

The combined effect of Capital Expenditure and Service Tariff on Income Tax is 47.3 (fortyseven point three) percent (Table 13). This means that Capex and Service Tariffs both contribute to an increase in Income Tax of 47.3 percent (fortyseven point three), with the remainder influenced by other factors not examined in this study (52.71 percent).

Table 13: Model Summary

\begin{tabular}{|c|c|c|c|c|}
\hline Model & $\mathbf{R}$ & R Square & Adjusted R Square & Std. Error of the Estimate \\
\hline 1 &, $687^{\text {a }}$ &, 473 &, 577 & 740,798 \\
\hline
\end{tabular}

a. Predictors: (Constant), Y1 Capex, Y2 Service Tariffs

b. Dependent Variable: Revenue

Each variable has a partial positive effect on income. The impact of Capex on taxes shown in Table 14 is 11.51 percent $(2.199 \times 5.234)$. In comparison, the effect of the Service Tariff on Income Tax is only 35.78 percent $(4,988 \times 7,174)$.

Table 14: Coefficients ${ }^{\mathrm{a}}$

\begin{tabular}{|cc|c|c|}
\hline \multirow{2}{*}{ Model } & Standardized Coefficients & Correlations \\
\cline { 3 - 4 } & Y1 & Beta & Zero-order \\
\cline { 2 - 4 } & Y2 & 2,199 & 5,234 \\
\hline
\end{tabular}

a. Dependent Variable: Z1- Tax 
According to the study's findings, Frequency License Fees (BHP Frequency) associated with the operation of Telecommunication Services may influence service providers' decisions, where higher expenses can lead to higher operating costs and a lower return on capital spent and investment. However, data testing results show that BHP Frequency does not affect the first model of the study. According to the findings of hypothesis testing, BHP Frequency has no significant effect on Capex as a measure of company investment. Frequency BHP contributed only 0.4 (zero point four) percent. Statistical testing also reveals that Capital Expenditure has no significant effect on revenue, with a 3.3(three points three) percent influence contribution. The first model, which examines the relationship and impact of BHP Frequency on Capex and its effect on revenue, demonstrates that the contribution value is minimal and has no significant effect on any changes in income received by the organizers. BHP Frequency is unlikely to stifle the development of telecommunications infrastructure for economic development. In general, the frequency BHP charged to service providers does not reduce investment in telecommunications infrastructure development, slowing growth and productivity. Network operators and operators define network licenses as Spectrum License Fees that are included in Assets that are amortized annually. According to Matheson \& Petit (2017), a spectrum license fee is a payment made by the operator in advance that is valid for the license term and can be recorded as a long-term investment (15 years). The license fee is calculated as part of the operator has or network operator's fixed cost structure (Fixed Cost), along with the investment and Overhead Cost.

The spectrum license fee is a Sunk Cost that has no bearing on future investments (Marsden \& Traber, 2017). According to Marsden \& Traber (2017), Sunk Cost ignores the repetitive nature of auctions and investments in the telecommunications sector; when the spectrum is valued at more than market value, it can reduce its profits, which primarily become the return on investment. The spectrum license price has a unique structure, with a large advance payment typically financed internally by the company winning the tender, followed by an annual fee paid as a smaller rental fee (Marsden \& Traber, 2017). This structure causes the licensee's funds to be diverted to more profitable investments, causing the company's investment management to allocate fewer funds for high spectrum costs (Marsden \& Traber, 2017).

As an important requirement in developing telecommunications infrastructure, tax regulations take into account the effect of network externalities arising from the telecommunications service sector when imposing taxes on operators. The tax system was identified as a source of uncertainty for investors in the telecommunications sector, resulting in lower investment levels, implying that taxes could be a significant barrier to investment. Taxes and Fees related to the provision of Telecommunication Services can influence the decisions of Service Providers, where higher expenses can lead to higher operating costs and reduce returns on capital expended and investment (McKenzie \& Mintz, 1992). The impact of less effective taxation is likely to limit the development of telecommunications infrastructure for economic development. The tax burden and fees charged on service providers have the potential to reduce investment capacity in the development of telecommunications infrastructure, thereby reducing growth and productivity (GSMA, 2013). Tax and fee regulations are important requirements in developing telecommunications infrastructure (World Bank, 2009). The effects of network externalities arising from the telecommunications service sector must also be considered when assessing the impact of Taxes and Fees charged on the Operator (GSMA, 2014).

The second model, based on the findings of this study, depicts the effect of BHP Frequency on service tariffs. Statistical testing reveals that service rates significantly impact BHP frequency accounts for 19.3 (nineteen points three) percent. Service tariff affects revenue by contributing 11.9 percent, and it affects tax by contributing 35.78 (thirty-five point seventyeight) percent. Capital Expenditure also has a significant 11.51 (eleven points fifty-one) percent impact on Income Tax.

\section{CONCLUSION}

The sunk cost argument is proven in this study's frequency license fee for telecommunications operators based on efficiency testing using Data Envelopment Analysis. The testing of hypotheses for the research model also shows that the frequency 
license fee has no effect on capital expenditure as a measure of the operator's investment. During the research period, each organizer experienced a value of efficiency that was twice as high (frontier). In general, the auction mechanism for managing frequency spectrum licenses in Indonesia has not effectively put investment decisions into action.

According to the analysis findings, the operator uses the frequency license fee obtained through the auction mechanism as part of the basic cost. Each increase in the frequency auction price has a minor impact on the service price. Another factor that has an impact is competition (addition of customers, increased traffic), which is not included in the research. Service fees and taxes are increased as a result of frequency license fees. State revenue is generated by license fees added to the Non-Tax State Revenue component. Increased income, including taxes on corporate income and Value Added Tax from sales and purchase transactions made by the operator, generates state revenue from the tax sector from telecommunications activities.

It is worth noting that the higher the auction price, combined with the lower service fees that come from the increased competition, the more difficult it is for small businesses to win the auction. This condition implies that the winning bidder will remain under the control of the big organizers. Suggestions for the government include issuing a merger policy for small businesses to compete in spectrum auction offers with a large capacity as the capital in operator business activities.

We want to test the feasibility of including mediation variables such as network area coverage, investment, number of services, and total assets affected by frequency license fees to assess efficiency. In addition, we intend to include the length of the research period and the number of providers in future research. The test can also be expanded to compare the efficiency of ASEAN telecommunication operators.

\section{REFERENCES}

Bauer, J. (2003). Impact of License Fees on the Prices of Mobile Voice Service. Telecommunications Policy, 27, 417-434.

Buchheit, S. \& Feltovich, N. (2011). Experimental Evidence Of A Sunk-Cost Para- Dox: A Study Of Pricing Behavior In Bertrand-Edgeworth
Duopoly. International Economic Review, 52(2), 317-347.

Cambini, C. \& Garelli, N. (2017). Spectrum Fees and Market Performance: A Quantitative Analysis. Telecommunications Policy. Elsevier, 41(5), 355-366.

Campbell R. M. (1984). Economics, 9th Edition New York: McGraw-Hill Book Company, 118-121

Cooper, W.W., Seiford, L.M., \& Tone, K. (2006), Data Envelopment Analysis: A Comprehensive Text with Models, Applications, References and DEA-Solver Software. 2nd ed. New York: Springer.

Cramton, P. (2002). Spectrum Auctions. In Handbook of Telecommunications Economics, Edited by M. Cave et al., Amsterdam, Elsevier Science, 605-639.

Department of Communications and the Arts (DCA). (2017). Spectrum Pricing, Consultation Paper. Retrieved from: http://www.communications.gov.au.

GSMA. (2007). Taxation and growth in east Africa. Retrieved From: https://www.gsma.com/publicpolicy/wpcontent/uploads/2009/09/GSMA-Taxationand-the-growth-of-mobile-in-east-africa2007.pdf

GSMA. (2013). Bangladesh: Asia's untapped mobile broadband opportunity. Retrieved from:

https://www.gsma.com/mobilefordevelopm ent/wpcontent/uploads/2016/02/Bangladesh_Asias _untapped_mobile_broadband_oppurtunity. pdf

GSMA. (2014). Mobile Taxes and Fees A Toolkit of Principles and Evidence. Deloitte.

Retrieved From: https://www.gsma.com/publicpolicy/wpcon tent/uploads/2016/09/GSMA2014_Report_ MobileTaxesAndFeesAToolkitOfPrinciplesAn dEvidenceKeyFindings-1.pdf

GSMA. (2019). The Impact of Spectrum Prices on Consumers. Retrieved From: https://www.gsma.com/spectrum/wpcontent/uploads/2019/09/Impact-ofspectrum-prices-on-consumers.pdf

Haan, M. A., \& Toolsema, L. A. (2011). License Auctions When Winning Bids Are Financed Through Debt. Journal of Industrial Economics, 59(2), 254-281. 
Hazlett, T., R. Munoz, \&D. Avanzini. (2011). What Really Matters in Spectrum Allocation Design. George Mason University Law and Economics Research Paper Series, 11-48.

International Finance Group- IFG. (2009). A Handbook for Tax Simplification.

ITU. (2014). ITU-R SM.2012. Economic aspects of spectrum management. SM Series Spectrum Management.

ITU. (2016). Guidelines For The Review Of Spectrum Pricing Metho- Dologies And The Preparation Of Spectrum Fees Schedules. ISBN: 978-92-61-19651-6 (paper version) 978-92-61-19661-5 (electronic version). Retrieved From: https://www.itu.int/en/ITU-D/SpectrumBroadcasting/Documents/Publications/Guid elines_SpectrumFees_Final_E.pdf.

ITU-R. Radiocommunication Sector of ITU. (2018). Guidance on the Regulatory Framework for National Spectrum Management. SM Series Spectrum Management. Retrieved From: https://www.itu.int/dms_pub/itur/opb/rep/R-REP-SM.2093-3-2019-PDFE.pdf

Janssen, M. C. W., \& Karamychev, V. A. (2009). Auctions, aftermarket competition, and risk attitudes. International Journal of Industrial Organization, 27(2), 274-285.

Jerry Ellig and James Nicholas Taylor. The Consumer Costs of Wireless Taxes and Surcharges. Working Paper in Regulatory Studies, Mercatus Center. Loyola Consumer Law Review, Vol. 19, \#1.

Kuroda, T., \& M. Del Pilar B. F. (2017). The Effects Of Spectrum Allocation Mechanisms On Market Outcomes: Auctions Vs. Beauty Contests. Telecommunications Policy, forthcoming.

Kwerel. (2000). Spectrum Auctions Do Not Raise the Price of Wireless Services: Theory and Evidence. Office of Plans and Policy Federal Communications Commission

Marsden, R., Ihle, H. M., \& Traber, P. (2017). The Impact of High Spectrum Costs on Mobile Network Investment and Consumer Prices. Retrieved From:https://www.nera.com/content/dam/n era/publications/2017/PUB_High_Spectrum_ Costs_0517.pdf.
Matheson, T., \& Petit, P. (2017). Taxing Telecommunications in Developing Countries. IMF Working Paper. International Monetary Fund. WP/17/247.

McKenzie, K. J. \& Mintz, J. M. (1992). Tax Effects on The Cost of Capital. National Bureau of Economic Research; University of Chicago Press; Canada-Us Tax Comparisons, 189 216.

Morris, A. C. (2005). Spectrum Auctions: Distortionary Input Tax or Efficient Revenue Instrument?. Telecommunications Policy, 29(9-10): 687-709.

Offerman, T, \& Potters, J. (2006). Does Auctioning of Entry Licenses Induce Collusion? An Experimental Study. The Review of Economic Studies, 73(3), 769-791.

Park, M., Lee, S.W. \& Choi. Y. J. (2010). Does Spectrum Auctioning Harm Consumers? Lessons From 3G Licensing. Information Economics and Policy, 23(2010), 118-126.

Tuerck, D., Bachman, P., Titch, S., \& Rutledge, J., (2007). Taxes and Fees on Communication Services. Retrieved form http://www.beaconhill.org/BHIStudies/Telec om/07MayBHIHeartlandTelecomTaxes.pdf.pdf

World Bank. (2009). Transforming Africa's infrastructure. Retrieved from: https://documents1.worldbank.org/curated/ en/246961468003355256/pdf/521020PUB0 EPI11010fficial0Use0Only1.pdf

\section{ABOUT THE AUTHORS}

Siti Kurnia Rahayu, email: siti.kurnia@email.unikom.ac.id

Siti Kurnia Rahayu, Department of Accounting, Universitas Komputer Indonesia, Bandung, Indonesia.

Aju Widya Sari, Directorate of Telecommunication of Kementerian Kominfo, Indonesia. 